\title{
Impact Strength of Natural Fibre Composites Measured by Different Test Methods: A Review
}

\author{
Namasivayam Navaranjan ${ }^{1, a}$ and Thomas Neitzert ${ }^{2}$ \\ ${ }^{1}$ School of Applied Sciences and Mathematics, Universiti Teknologi Brunei, Jalan Tungku Link, Gadong BE1410, \\ Brunei Darussalam \\ ${ }^{2}$ School of Engineering, Computer and Mathematical Sciences, Auckland University of Technology, Private Bag \\ 92006, Auckland 1142, New Zealand
}

\begin{abstract}
Different types of impact test methods have been used in recent years to measure the impact resistance of natural fibre composites (NFCs). After reviewing the literature, the impact resistance of flax, hemp, sisal, wood and jute fibre composites that were measured using different test methods have been compared and discussed. It has been learned that the test methods were selected for research interest, industry requirement or availability of test equipment. Each method had its own advantages and limitations. The result from a particular test could be compared but not with the result from other test methods. Most impact test methods were developed for testing ductile-brittle transition of metals. However, each NFC has a different morphology and cannot be comparable to metals in failure mode and energy absorption characteristic during an impact test. A post evaluation of morphology of an NFC sample after an impact test is important to characterise the material.
\end{abstract}

\section{Introduction}

Natural fibre composites (NFC) are made of a polymer matrix reinforced with cellulose-based plant fibres such as flax, hemp, sisal, wood and jute. They are receiving increasing attention in automobile, building and other engineering applications. The composites are cost effective, and have low density, high specific strength and disposability. Furthermore, most of NFCs are recyclable while the natural fibre and biopolymer composites can be biodegradable [1]. NFCs have good electrical and chemical resistance. They also possess good thermal and acoustic insulating properties.

Despite many advantages of NFCs, their impact strength is low compared to synthetic fibre composites [2]. Impact resistance is the ability of a material to withstand a shock loading or an applied stress at high speed. Impact behaviour is an important mechanical property of engineering materials that are used for many popular applications including interior and exterior components of automobiles, buildings, aircrafts and many more. It depends on a number of parameters such as strength, elastic modulus, length and orientation of fibres, and fibre-matrix interfacial bond strength. It also depends on the type of test method used to measure the impact energy.

There are two categories of impact tests: low velocity impact, and high velocity impact [3]. Charpy, Izod and drop weight impact tests fall into the first category while the ballistics impact test falls into the second category. Charpy and Izod impact test methods are also known as pendulum method and

\footnotetext{
${ }^{a}$ Corresponding author: nava.navaranjan@utb.edu.bn
} 
are simple and easy to perform [4]. The method determines the amount of energy absorbed by notched or unnotched sample of a material during fracture. The absorbed energy is a measure of a given material's toughness and acts as a tool to study the ductile-brittle transition temperature.

Drop weight impact tests are generally used to test the impact behaviour of composite plates and components [5]. This test can closely resemble impact damage that could occur during in-service. Two categories of damages can be observed after a drop weight impact test. The first category is macro-damages that can be visible to the naked eye and the second is at microscale that can seldom be seen by the naked eye. Evaluation of both types of damage can be enhanced through the use of postimpact testing.

Low velocity impact test instruments can be modified to be sophisticated and instrumented impact test devices. These devices have three major components: the dynamic load cell (called tup), the data display system, and the signal processing unit [6]. The tup is placed on the impactor used to strike the specimen. The tup consists a strain gauge that measures the change in strain vs. time as the impactor strikes the specimen. The measured load and strain against the time can provide impact behaviour of a sample from the initiation to the end of failure.

The ballistics test is used to evaluate the impact resistance of composite panels and products such as composite armor [7]. The test involves the firing a high speed projectile at a product of interest and determining the localized the damage after the impact.

A review of impact test methods that are commonly used for NFCs are briefly presented in this paper. The impact resistance of some flax, hemp, sisal, wood and jute fibre composites that were measured using different test methods are compared and discussed. Finally, the benefits and limitations of using each method for NFCs are presented.

\section{Impact test method}

\subsection{Pendulum method}

In this method, a pendulum of a known weight is hoisted to a known height and allowed to fall and strike a specimen clamped at the bottom of the swing. The pendulum continues to swing up after breaking the specimen to a height somewhat lower than that of a free swing. The energy lost by the pendulum is measured as the impact energy of the specimen. Izod and Charpy use the same principle to measure the impact resistance [5]. The difference in both methods is that in the Charpy impact test the specimen is supported as a simple beam, and in the Izod impact test the specimen is supported as a cantilever. They also have different test procedure and specimen geometry as given in Table 1 .

Table 1. Izod and Charpy test requirements.

\begin{tabular}{|l|l|l|}
\hline \multicolumn{1}{|c|}{ Procedure } & \multicolumn{1}{c|}{ Izod } & \multicolumn{1}{c|}{ Charpy } \\
\hline Common standards & $\begin{array}{l}\text { ASTM D256 or ISO 180 for } \\
\text { notched specimens } \\
\text { ASTM D4812 ISO 180 } \\
\text { unnotched specimens }\end{array}$ & $\begin{array}{l}\text { ASTM A370, ISO 148 or EN } \\
10045-1\end{array}$ \\
\hline Test sample & Placed in vertical position & Placed in horizontal position \\
\hline $\begin{array}{l}\text { Test hammer } \\
\text { striking }\end{array}$ & At the upper tip of specimen & $\begin{array}{l}\text { At point of notch but in } \\
\text { opposite direction }\end{array}$ \\
\hline Notch face & $\begin{array}{l}\text { Facing the striker, fastened in } \\
\text { a pendulum }\end{array}$ & $\begin{array}{l}\text { Face is positioned away from } \\
\text { the striker }\end{array}$ \\
\hline Notch type & V-notch & V and U notches \\
\hline $\begin{array}{l}\text { Specimen } \\
\text { dimensions }\end{array}$ & $75 \times 10 \times 10 \mathrm{~mm}$ & $55 \times 10 \times 10 \mathrm{~mm}$ \\
\hline Hammer type & Farming hammer as striker & Ball Pin hammer as striker \\
\hline
\end{tabular}




\subsection{Drop weight impact test}

The test is performed according to ASTM 7136. A known weight is dropped in a vertical direction and the impact energy is calculated from the dropped height. Since the falling weight either stopped on the test specimen, or destroyed the specimen completely and passed through it, the only result that could be obtained is of a pass or fail the test [8]. Falling weight impact have the following advantages over other methods:

- It is used for samples of moulded parts, plates and sheets.

- Failures originate at the weakest point in a sample and propagate from there. The failure propagation has no preferential direction.

- Samples don't have to shatter to be considered failures. Failure can be defined by deformation, crack initiation, or complete fracture, depending on the requirements.

\subsection{Instrumented impact test}

Instrumented impact test devices are made with electronic sensing instrumentations that can record the load on the test specimen continuously as a function of time and specimen deformation prior to fracture. The instruments can record strain or stress against time for the entire period of an impact test. The data from the acquisition system provides complete representation of impact test history rather than a value from a single calculated number. Another advantage is that the test times can be reduced because of its automated data acquisition system [9]. Instrumented drop weight and pendulum test equipment are considered to be the best general impact tests devices presently available. A very complete impact profile can be developed for an NFC using multiple tests at various rates. This approach is useful for simulation and comparison of NFC's functional impact resistance. There is enough flexibility to simulate real life conditions from multiple test data and perform audit inspections on samples, parts or moulded components.

\subsection{Ballistics test}

The European EN 1522 / 1523 and ASTM E3062 standards describe the Ballistics test. It is a high speed testing that is useful for the ultimate impact strength of composites. The ballistics testing is done by firing an impactor traveling in the range of 400-2000 m/s [10]. The Ballistics method consists of firing a high speed projectile at an object and determining after the impact how localized the damage is. Structural response of a material is less important in high velocity impact than in a low velocity condition. The damage area is more localized by the impact and the geometrical consideration is less important. This is a good method for testing impact resistance of natural fibre composites, and has been used for testing products such as composite panels, armors and windscreens of aircraft.

\section{Impact strength of natural fibre composites}

The impact strength of some natural fibre composites of flax, hemp, sisal, wood and jute are given in Table 2. The type of matrix and the impact test method used for each composite are also listed in Table 2. 
Table 2. Impact strength of selected natural fibre composites

\begin{tabular}{|c|c|c|c|c|c|c|c|}
\hline Matrix/process & $\begin{array}{l}\text { Fibre/type of } \\
\text { orientation }\end{array}$ & $\begin{array}{l}\text { Fibre } \\
\text { Content } \\
\text { (\%) }\end{array}$ & $\begin{array}{l}\text { Izod } \\
\text { Test } \\
\left(\mathrm{kJ} / \mathrm{m}^{2}\right. \\
\text { or } \\
\mathrm{J} / \mathrm{m}) \\
\end{array}$ & $\begin{array}{l}\text { Charpy } \\
\text { Test } \\
\left(\mathrm{kJ} / \mathrm{m}^{2}\right. \\
\text { or } \mathbf{J} / \mathbf{m})\end{array}$ & $\begin{array}{l}\text { Drop } \\
\text { Test }\end{array}$ & $\begin{array}{l}\text { Ballistics } \\
\text { Test }\end{array}$ & Reference \\
\hline PP & $\begin{array}{l}\text { Flax yarn } \\
\text { (aligned) } \\
\text { Pultruded flax }\end{array}$ & 30 & & 88 & & & [11] \\
\hline $\mathrm{PP} / \mathrm{CM}$ & $\begin{array}{l}\text { Flax (aligned) } \\
\text { needle punched } \\
\text { flax/PP mats }\end{array}$ & 50 & 751 & & & & [12] \\
\hline UP/RTM & Flax (random) & 40 & & 33 & & & {$[13]$} \\
\hline $\begin{array}{l}\text { PP/ Rubbery } \\
\text { MAPP coupled } \\
\text { IM }\end{array}$ & Flax & 30 & & 22 & & & [14] \\
\hline PP & Flax IM & 30 & & 18 & & & {$[15]$} \\
\hline Vinyl ester & Flax mat & 30 & & & $\begin{array}{l}\text { Force }= \\
3.5 \mathrm{kN} \\
\text { Energy } \\
=65 \%\end{array}$ & & [16] \\
\hline Epoxy/CM & Hemp (random) & 65 & & 15 & & & [17] \\
\hline $\mathrm{PLA} / \mathrm{CM}$ & $\begin{array}{l}\text { Hemp (carded) } \\
\text { alkali treated }\end{array}$ & 30 & & 9 & & & [18] \\
\hline $\mathrm{PLA} / \mathrm{CM}$ & $\begin{array}{l}\text { Hemp (aligned) } \\
\text { wrap spun alkali } \\
\text { treated short } \\
\text { hemp hybrid } \\
\text { yarn }\end{array}$ & 30 & & 19 & & & [19] \\
\hline PLA/CM & $\begin{array}{l}\text { Hemp (biaxial) } \\
\text { wrap spun } \\
\text { bleached hemp } \\
\text { hybrid yarn, }\end{array}$ & 45 & & 25 & & & [20] \\
\hline PLA/CM & Hemp (DSF) & 30 & & 11 & & & {$[17]$} \\
\hline $\begin{array}{l}\text { PP/MAPP } \\
\text { coupled IM }\end{array}$ & Hemp & 40 & 210 & & & & [21] \\
\hline PLA & Sisal (random) & 30 & 3.3 & & & & {$[22]$} \\
\hline $\begin{array}{l}\text { PLA/PEG- } \\
\text { plasticized }\end{array}$ & Sisal & 30 & 4.5 & & & & [22] \\
\hline Epoxy & $\begin{array}{l}\text { Sisal } \\
\text { (unidirectional) }\end{array}$ & 30 & 22 & & & & [23] \\
\hline UFR & Sisal (random) & 50 & & $\begin{array}{l}9.5 \text { (un- } \\
\text { notched) }\end{array}$ & & & [24] \\
\hline Epoxy & Sisal (aligned) & 30 & & & & $\begin{array}{c}\text { Energy }= \\
106 \mathrm{~J}\end{array}$ & [25] \\
\hline PER/MEK & $\begin{array}{l}\text { Curaua } \\
\text { (aligned) }\end{array}$ & 30 & & 140 & & & [26] \\
\hline PP & Wood (flour) & 30 & 5 & & & & [24] \\
\hline PP/EPR/MAPP & Wood (flour) & 30 & 7 & & & & [24] \\
\hline PP/MAEPDM & Wood (flour) & 30 & 7 & & & & [24] \\
\hline PP/MAPP & Wood (flour) & 30 & 5 & & & & [24] \\
\hline
\end{tabular}

\begin{tabular}{|c|c|c|c|c|c|c|c|}
\hline Matrix/process & $\begin{array}{l}\text { Fibre/type of } \\
\text { orientation }\end{array}$ & $\begin{array}{l}\text { Fibre } \\
\text { Content } \\
(\%)\end{array}$ & $\begin{array}{l}\text { Izod } \\
\text { Test } \\
\left(\mathrm{kJ} / \mathrm{m}^{2}\right. \\
\text { or } \\
\mathrm{J} / \mathrm{m})\end{array}$ & $\begin{array}{l}\text { Charpy } \\
\text { Test } \\
\left(\mathbf{k J} / \mathbf{m}^{2}\right. \\
\text { or } \mathbf{J} / \mathbf{m})\end{array}$ & $\begin{array}{l}\text { Drop } \\
\text { Test }\end{array}$ & $\begin{array}{l}\text { Ballistics } \\
\text { Test }\end{array}$ & Reference \\
\hline $\begin{array}{l}\text { PP/ MAPP } \\
\text { coupled IM }\end{array}$ & Wood (BKP) & 40 & 40 & & & & {$[27]$} \\
\hline PP & $\begin{array}{l}\text { Wood, TMP } \\
\text { (fibre length } \\
=3.0 \mathrm{~mm} \text { ) }\end{array}$ & 40 & 5.5 & & & & [28] \\
\hline PP/MAPP & Wood, MDF & 30 & 4 & & & & [29] \\
\hline $\begin{array}{l}\text { Unsaturated } \\
\text { polyester }\end{array}$ & Jute mat & 30 & 6 & & $\begin{array}{c}\text { Initiation } \\
\text { energy } 8 \\
\mathrm{~J}, \mathrm{Max} \\
\text { energy } \\
\text { 13J }\end{array}$ & & {$[30]$} \\
\hline $\begin{array}{l}\text { Polyester, } 10 \% \\
\mathrm{NaOH}\end{array}$ & Jute & 18 & & 3.25 & & & [31] \\
\hline Epoxy & Jute, chopped & 30 & 115 & & & & {$[32]$} \\
\hline
\end{tabular}

$\mathrm{RTM}=$ Resin transfer moulding; $\mathrm{CM}=$ Compression moulding; $\mathrm{IM}=$ Injection moulding 
$\mathrm{PP}=$ poly propylene $; \mathrm{EPR}=$ ethylene propylene-diene $; \mathrm{PEG}=$ polyethylene glycol; $\mathrm{MAPP}=$ maleated $\mathrm{PP}$;

MAEPDM = maleated ethylene-propylene-diene elastomer; $\mathrm{PER}=$ polyester resin; $\mathrm{MEK}=$ metyl-ethyl-ketone;

UFR $=$ urea-formaldehyde resin

$\mathrm{BKP}=$ bleached kraft pulp; PALF $=$ pineapple leaf fibre.

PHB = poly (3-hydroxybutyrate); PLLA = L-polylactide acid; PA = Polyamide .

MAA-PP = maleic acid anhydride modified PP.

$\mathrm{CSM}=$ chopped strand mat; DSF $=$ Dynamic sheet forming; TMP $=$ thermo-mechanical pulp; $\mathrm{MDF}=$ medium density fibre

\section{Comparison of different impact test methods}

NFCs have growing interest in engineering, building and furniture applications that require impact resistance. Hence, a comparison of available impact test methods can help in choosing single or combination of correct test methods to obtain reliable and accurate impact properties. Izod and Charpy impact tests are easy and fast methods that allow to generate large amounts of data. However, the results obtained are not in-depth as well as do not reveal a great details about the impact property of material. These methods are cost effective to use as they can easily be set up to test a great number of specimens and generate a large amount of data within a short period of time.

Izod and Charpy methods were initially developed for metals and the test results were commonly used to compare the impact response of the materials. Metals are isotropic materials that are different from NFCs in composition, microstructure and manufacturing condition [33]. These method can miss important information of test specimen behaviour and characteristic of the material during the impact event and can provide misleading information of impact strength. For example, composites can fail internally but display no damage externally. Sophisticated instruments that consist of high speed photography are able to produce results showing the propagation of the crack induced by the impact load. These instruments allow the user to measure the force and/or strain more accurately. The data, however, may not be suitable for some composite materials due to the anisotropic nature of the material [34]. For these composites, results from an impact test have limitation to provide the overall behaviour of the materials. Furthermore, the simplistic nature of impact testing and test results from an NFC have limited post impact test methods that can be used for detail analysis of impact behaviour.

The drop weight impact test method is commonly used to evaluate the impact behaviour of a product or component that is normally from a "real world" application and cannot be tested using the Charpy or Izod instrument. The drop weight method can provide greater amount of information on the behaviour of a composite, for example, characteristics of interfaces of laminated composites [35]. The drop weight impact method also allows different configurations to be used depending on geometry and size of samples. Therefore, drop weight testing tends to be the preferred method when using low velocity impact testing. Drop weight testing results may be enhanced through post impact testing.

Natural fibre laminated composites can be subjected to delamination due to their low intraluminal strength. Shear and normal stresses can occur in the boundary layer of laminates under transverse and normal loading. The polymeric matrix of a composite shares the energy among the constituents and makes the composite to absorb impact energy. A low velocity impact state does not produce perforation, but creates delaminations between the layers with no visible damage on surfaces [36]. A composite may also have pre-existing delamination due to contaminated reinforcing fibres, insufficient wetting of fibres, machining and mechanical loading and the lack of reinforcement in the thickness direction [37]. Such defects can reduce the energy absorbing ability of a composite.

The mechanism and mode of failure of NFC can be affected by a few parameters due to low velocity impact loading conditions, i.e. fibre-matrix interface, type of fibre layup, specimen thickness, velocity and type of impactor [38]. Metals generally undergo elasto-plastic deformation prior to failure. Hence, they absorb energy during both elastic and plastic deformations during an impact test. Composite laminates have negligible plastic deformation and mostly absorb energy during elastic deformation. Since most composites are brittle in nature, they can absorb energy during elastic deformation and each composite can have similar damage mechanisms. 
Ballistics is a high velocity test and cannot be directly compared to the Charpy, Izod and drop weight tests. It is complicated since a high velocity impactor is involved in the test. However, the Ballistics test is important when a sample of structural components should be assessed under an impact loading condition that is closer to reality. The Ballistics test is highly effective in replicating the behaviour of the composite components at high speed impact.

\section{References}

1. Md. S. Islam, A. Kovalcik, M. Hasan, V. K. Thakur. Natural Fiber Reinforced Polymer Composites. International Journal of Polymer Science. (2015).

2. K.L. Pickering, M.G. Aruan Efendy, T.M. Le. A review of recent developments in natural fibre composites. Composites: Part A 83 (2016) 98-112.

3. R. Zah, R. Hischier, A.L. Leao, I. Braun. Curaua fibers in the automobile industry - A sustainability assessment. Journal of Cleaner Production. 15(2007) 1032-1040.

4. M. Nagai H. Miyairi. The Study on Charpy impact testing method of CFRP; Advanced Composite Materials: The Official Journal of the Japan Society of Composite Materials. 3 (1994) 177-190.

5. S.N.A. Safri, M.T.H. Sultan, N. Yidris, F. Mustapha. Low Velocity and High Velocity Impact Test on Composite Materials - A review. The International Journal of Engineering and Science. 3 (2014) 50-60.

6. C. Clemons, A. R. Sanadi. Instrumented Impact Testing of Kenaf Fiber Reinforced Polypropylene Composites: Effects of Temperature and Composition. Journal of Reinforced Plastics and Composites. (2007).

7. F. S. da Luza, E. P. L. Juniora, L. H. L. Louroa, S. N. Monteiro. Ballistic Test of Multilayered Armor with Intermediate Epoxy Composite Reinforced with Jute Fabric. Materials Research. 18(2015).

8. C.V. Srinivasa, K.N. Bharath. Impact and Hardness Properties of Areca Fiber-Epoxy Reinforced Composites. J. Mater. Environ. Sci. 2 (4) (2011) 351-356.

9. A. Malhotra \& F. J. Guild. Impact Damage to Composite Laminates: Effect of Impact Location. Appl Compos Mater 21 (2014) 165-177.

10. S. D. Rossoa, L. Iannuccia, P. T. Curtis. On the ballistic impact response of microbraid reinforced polymer composites. Composite Structures 137 (2016) 70-84.

11. I. Angelov, S. Wiedmer, M. Evstatiev, K. Friedrich, M. G. Pultrusion of a flax/ polypropylene yarn. Composites Part A, 38(5) (2007)1431-8.

12. K. Oksman. Mechanical properties of natural fibre mat reinforced thermoplastic. Appl Compos Mater, 7(5-6) (2000) 403-14.

13. Z. Li, X. Zhou, and C. Pei. Effect of Sisal Fiber Surface Treatment on Properties of Sisal Fiber Reinforced Polylactide Composites. International Journal of Polymer Science. 2011(2011).

14. M. H. B. Snijder, H. L. Bos. Reinforcement of polypropylene by annual plant fibers: optimisation of the coupling agent efficiency. Compos Interfaces 7 (2) (2000) 69-79.

15. A. K. Bledzki, A. A. Mamun, M. Lucka, V. S. Gutowsk. The effects of acetylation on properties of flax fibre and its polypropylene composites. Express Polym Lett 2(6) (2006) 413-22.

16. A. Pavlovic, C. Fragassa, C. Santulli. Experimental Analysis of Mechanical Properties of Composites Reinforced by Flax and Basalt Natural Fibers. 5th Conference on Natural Fibre Composites, Rome 15-16 October 2015.

17. M. S.Islam, K. L.Pickering, N. J. Foreman. Influence of alkali fiber treatment and fiber processing on the mechanical properties of hemp/epoxy composites. J Appl Polym Sci 119(6) (2011) 3696-707.

18. I. S. Islam, K. L. Pickering, N. J. Foreman. Influence of alkali treatment on the interfacial and physico-mechanical properties of industrial hemp fibre reinforced polylactic acid composites. Composites Part A, 41(5) (2010) 596-603. 
19. B. Baghaei, M. Skrifvars, M. Salehi, T. Bashir, M. Rissanen, P. Nousiainen. Novel aligned hemp fibre reinforcement for structural biocomposites: porosity, water absorption, mechanical performances and viscoelastic behaviour. Composites Part A, 61 (2014) 1-12.

20. I. Van de Weyenberg, J. Ivens, A. De Coster, B. Kino, E. Baetens, I. Verpoest. Influence of processing and chemical treatment of flax fibres on their composites. Compos Sci Technol 63(9) (2003) 1241-6.

21. M. Sain, P. Suhara, S. Law, A. Bouilloux. Interface modification and mechanical properties of natural fiber-polyolefin composite products. J Reinf Plast Compos 24(2) (2005) 121-30.

22. M. K. Guptaa, R. K. Srivastava. Properties of sisal fibre reinforced epoxy composite. Indian Journal of Fibre \& Textile Research. 41(2016), 235-241.

23. J. B. Zhong, J. Lv, C. Wei. Mechanical properties of sisal fibre reinforced ureaformaldehyde resin composites. eXPRESS Polymer Letters. 1(10) (2007) 681-687.

24. G. Keledi, A. Sudár, Ch. Burgstaller, K. Renner, J. Móczó, B. Pukánszky. Tensile and impact properties of three-component PP/wood/elastomer composites. eXPRESS Polymer Letters 6(3) (2012) 224-236.

25. B. M. de Araújo, E. P. Lima, L. H. L. Louro, S. N. Monteiro. Ballistic Performance of Sisal Fibre Reinforced Epoxy Composite in Multilayered Armor. $21^{\circ}$ CBECIMAT - Congresso Brasileiro de Engenharia e Ciência dos Materiais 09 a 13 de Novembro de 2014, Cuiabá, MT, Brasil.

26. A. da S. FerreiraI, F. P. D. LopesI, S. N. MonteiroI, K. G. Satyanarayana. Charpy impact resistance of alkali treated curaua reinforced polyester composites. Revista Matéria, 15(2) (2010), 131-137.

27. H. J. Li, M. M. Sain. High stiffness natural fiber-reinforced hybrid polypropylene composites. Polym Plast Technol Eng., 42(5) (2003):853-62.

28. A. Thumm, A. R. Dickson. The influence of fibre length and damage on the mechanical performance of polypropylene/wood pulp composites. Composites: Part A, 46 (2013) 45-52.

29. A. R. Dickson, D. Even, J. M. Warnes, A. Fernyhough. The effect of reprocessing on the mechanical properties of polypropylene reinforced with wood pulp, flax or glass fibre. Composites: Part A, 61 (2014) 258-267.

30. E. Elbadry, H. Hamada. Impact Properties of Natural Jute Fabric/Jute Mat Fiber Reinforced Polymer Matrix Hybrid Composites. Journal of Mechanics Engineering and Automatio, 2 (2012) 381-388.

31. A. Gopinatha, M. S. Kumar, A. Elayaperumal. Experimental Investigations on Mechanical Properties of Jute Fiber Reinforced Composites with Polyester and Epoxy Resin Matrices. 12th GLOBAL CONGRESS ON MANUFACTURING AND MANAGEMENT, GCMM 2014.

32. R. Naveenkumar, V. Sharun, B. Dhanasakkaravarthi, P. T. I. Rajakumar. Comparative study on jute and Kenaf fiber composite material. Int. Journal of Applied Sciences and Engineering Research, 4(2), 2015.

33. Hufenbach, W., et al. Charpy impact tests on composite structures - An experimental and numerical investigation. Composites Science and Technology, 68 (2008), 2391-2400.

34. Ujihashi, Sadayuki. An intelligent method to determine the mechanical properties of composites under impact loading. Composite Structures, (1993) 149-163.

35. Meola, Carosena, Carlomagno, M. Giovanni. Impact damage in GFRP: New insights with infrared thermography. Composites: Part A (2010), 1839-1847.

36. H. Ghasemnejad, V. R. Soroush, P. J. Mason. To improve impact damage response of single and multi-delaminated FRP composites using natural Flax yarn. Materials and Design, (2012) 865873.

37. H. Ghasemnejad, A. S. M. Furquan, P. J. Mason. Charpy impact damage behaviour of single and multi-delaminated hybrid composite beam structures. Materials and Design, (2010) 3653-3660

38. C. Scarponi, C. S. Pizzinelli, S. Sanchez-Saez, and E. Barbero. Impact load behaviour of Resin Transfer Moulding (RTM) hemp fibre composite laminates. Journal of Biobased Materials and Bioenergy, 3(3) (2009), 298-310. 